\title{
The dynamics of value system in 1998 and 2015: Longitudinal research in Latvia
}

\author{
Marina Sokola-Nazarenko*, Kristine Martinsone, Sandra Mihailova, Jelena Levina, \\ and Elina Karsa \\ Rīga Stradinsš University, Latvia
}

\begin{abstract}
Values may change during life because a person obtains new life experience and competencies. In the past decade, many Latvian psychologists studied people's values and their connections with different factors like cultural, political, social, economic changes and other factors [1-3 and other]. Since 1994 Latvia has gone through different socialeconomic changes like crisis, economic growth, assumption to NATO and EU, and acceptation of euro currency. These changes can influence participants' values. The aim was to conduct a comparative longitudinal research in individuals' values in 1998 and 2015, at the beginning of their youth and then in adulthood, in order to answer the following questions: what values were in 1998 and 2015; what differences in values had appeared comparing 1998 and 2015 in same persons. Results showed that the most important values in 1998 and 2015 were "Family", "Love", "Responsibility", "Honesty" and "Cheerfulness". Significant changes appeared in "Health" that became significantly important in 2015 and replaced the importance of "Love". Most achievable values in 1998 and 2015 were "The beauty of nature and art" and "Cognition" but in 2015 also "Active life" which replaced "Self-confidence" that was important in 1998. Significant changes appeared in "Self-confidence", "Wisdom", "Active life", "Freedom", "Interesting job", "Learning" and "Friends" as well, where importance of some values increased and some decreased in 2015.
\end{abstract}

Key words: value system, Rokeach value theory, Fantalova value theory.

\section{Introduction}

Many studies of values and value relationships with social, political, economic, cultural and other factors were published in the past decade [1-7 and other]. Many of Latvian psychologists have been studying values since the end of the XX century and at the beginning of XXI because different socioeconomic changes appeared in Latvia between 1998 and 2015:

- 1992 - 1997 - financial and bank crisis,

- 1998 - 2007 - economic growth,

- 2004 - assumption to NATO and EU,

- 2014 the introduction of euro currency.

In the context of socioeconomic changes, it is important to study values because they reflect different factors like culture, social norms, experience and others in human daily life. Every

\footnotetext{
* Corresponding author: marina.sokola.nazarenko@gmail.com
} 
individual has its own idea of what is important in life. Relations, behaviour and decision making is strongly connected with our values [8].

On the social level, a lot of research works were published in the last 15 years in Latvia about values of adolescents and adults, as well as value connections with political, cultural and economic factors $[1-3,5,9]$. A person must acknowledge important values and abilities to create aims and successfully integrate into society.

The problem is that there has not been longitudinal research in Latvia of value dynamics. Therefore, we put forward the aim to find out what dynamics of values in the same persons is. Two study questions appeared - what values were in 1998 and 2015; what differences in values appeared comparing 1998 and 2015.

The idea is that values may change during the life because a person obtains new life experience and competencies while accepting changes. The concept of this study is based on the idea that during the life participants have obtained some new experience that has influenced their values and they have got a new sense of what is important in the life. According to the study questions, the theory is based on Milton Rokeach (1973) [10] value hierarchy theory and J.B. Fantalova (Е.В. Фанталова, 1992) important and achievable value theory [11].

Rokeach value theory provides the idea that everyone has terminal values, which determine personal or social orientation; and instrumental values, which are morality and competences that change during the life [12]. That means that terminal values are persons' beliefs tended to personality development or social acceptance. The instrumental values determine how person will realize his or her beliefs in real life.

Fantalova value theory is more personal and determines that there are two types of values - important and achievable. Achievable values are values that person may have in real life, but important ones - that person consider to be essential. Significant difference index between achievable and important values leads to internal conflict or self-vacuum [11]. It means that balance between important and achievable values is ability to evaluate correctly what resources person has and what person needs.

\section{Methods}

\subsection{Sample}

This study is based on a previous empirically conducted study in 1998. Then, after 17 years, the same participants were tested in 2015. Participants came from one Riga high school. Participants of the first study were $11^{\text {th }}-12^{\text {th }}$ form students in 1998 at the age of $16-18$ years; 66 women (57.36\%) and 49 men (42.61\%). In second study in 2015 (after 17 years) with the help of the Internet we tried to reach the same participants. Only $30(25 \%)$ responded to the request -20 women $(65.5 \%)$ and 10 men (34.5\%); at the age of 33 to 35 ( $M=33.9$; $S D=0.61$ ). In this study, data from the same 30 participants, obtained in 1998 and 2015, were compared and analyzed to receive the most reliable data.

Majority of the participants had acquired higher education $83.3 \%$, incomplete higher education - 10\%, professional high school education $-3.3 \%$. The biggest part of participants $-76.6 \%$ were employed, $16.7 \%$ - unemployed, $3.3 \%$ - did not work because of children in the family. As to the income level most of the participants answered that they could meet their needs - 93.3\% and $6.7 \%$ - could not. Also $33.3 \%$ were married, $23.3 \%$ - not married, $26.7 \%$ - had a civil marriage, $6.7 \%$ - divorced, $3.3 \%$ - free from relations, $3.3 \%$ - have a romantic relation, $3.3 \%$ - other. In this sample, $36.7 \%$ had at least 1 child, $30 \%$ were childless, $26.7 \%$ had 2 children, $6.7 \%$ had 3 or more children in their family. 


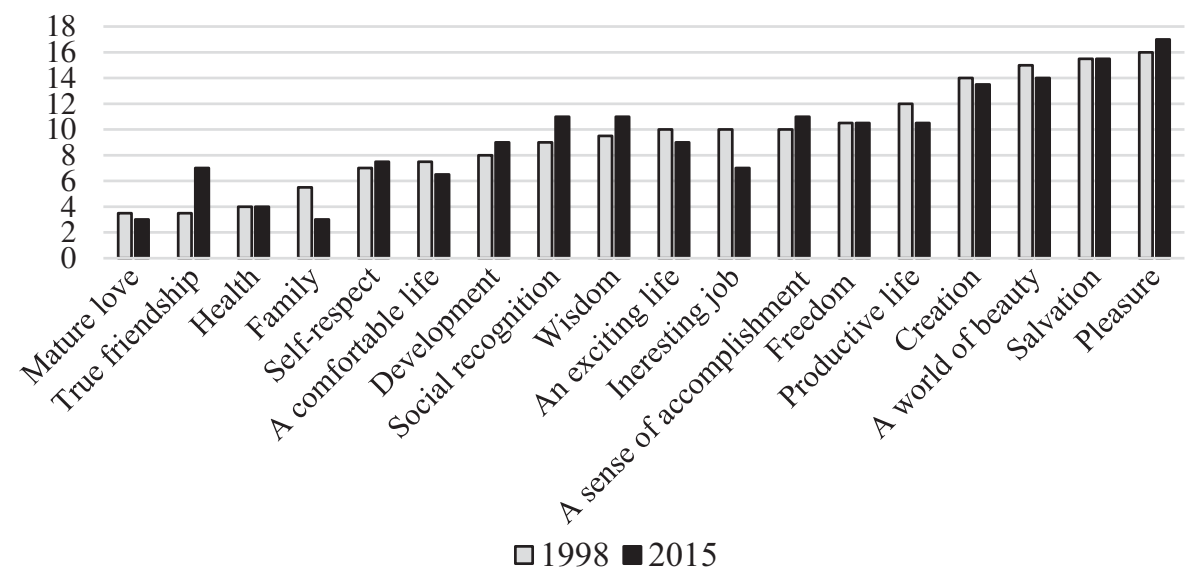

Fig. 1. Dynamics of terminal value hierarchy in 1998 and 2015 based on central tendency score where 1 - most important, 18 - less important.

\subsection{Materials}

Data were collected using the following questionnaires in order to determine values: J. Fantalovas questionnaire "Compliance level between "important" and "achievable" values in different aspects of life" (Методика "Уровень соотношения "иенности" и "доступности" в различных жизненных сферах, [11]; translation in Latvian S. Jirgena (now Mihailova), 1999) and "Rokeach Value Survey" [10] (translation in Latvian S. Jirgena (now Mihailova), 1999) [1].

Rokeach values were ranked in hierarchic division from " 1 " - most important to "18" less important value. There were two lists of 18 values "terminal" and "instrumental". Participant needed to range every list of values in hierarchic order.

Fantalova questionnaire is based on Rokeach value theory from which she took 12 terminal values and made two lists. Participants ranged hierarchically what values they think are most "important" - in the first list. In the second list, they checked what in their opinion the most "achievable" values are. That means that a participant compared each value to another in pairs (ex. Happy Family life - Good, reliable friends; Happy Family Life - Wisdom etc.) and chose which is more "important" and "achievable" in every pair. Results showed us which values were the most preferable for a person. Every result was ranged from " 0 " (less elected) to "11" (most elected) to understand what the hierarchy of "important" and "achievable" values is.

\section{Results}

\subsection{Rokeach "terminal" and "instrumental" values}

To answer the question what were the most important and the least important terminal and instrumental values (by Rokeach) in 1998 and 2015 the descriptive statistics was used. To analyze the difference level between two years the Wilcoxon criteria were used.

First of all terminal values in 1998 and 2015 were analyzed and arranged in hierarchic order (Fig. 1). The most important terminal values by Rokeach in 1998 were:

- $1^{\text {st }}$ rank - "Mature love" $(M=5.38 ; S D=5 ; M d n(I Q R)=3.5(1-8.25))$;

- $2^{\text {nd }}$ rank - "True friendship" $(M=4.65 ; S D=2.92 ; M d n(I Q R)=3.5(2-7))$;

- $3^{\text {rd }}$ rank - "Health" $(M=6.81 ; S D=5.7 ; M d n(I Q R)=4(2-11.5))$. 


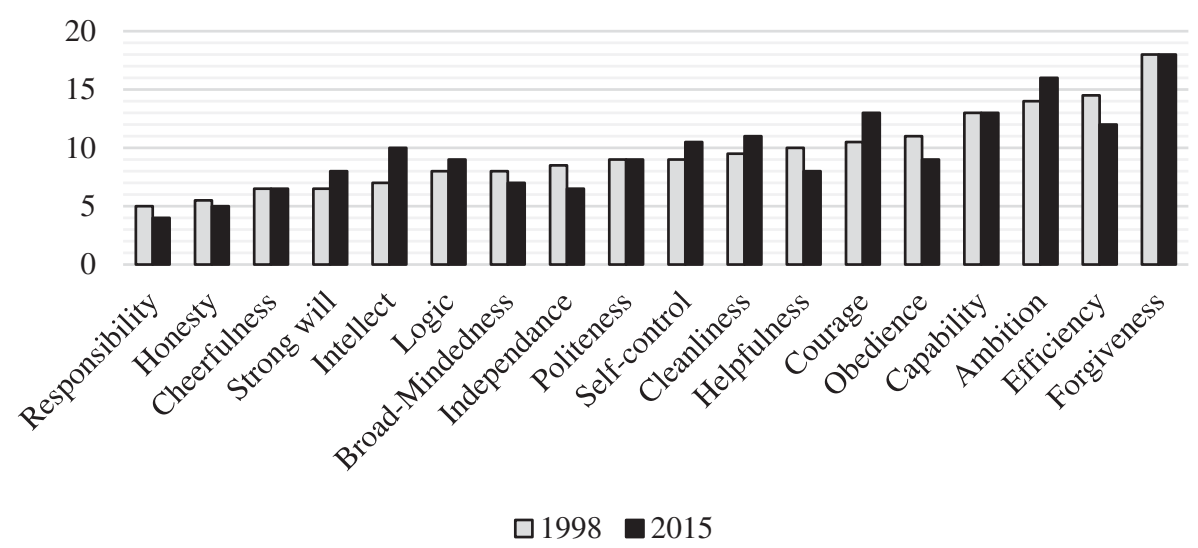

Fig. 2. Dynamics of instrumental value hierarchy in 1998 and 2015 based on central tendency score where 1 - most important, 18 - less important.

The most important terminal values by Rokeach in 2015 were:

- $1^{\text {st }}$ rank - "Family" $(M=4.6 ; S D=4.95 ; M d n(I Q R)=3(1-5))$;

- $2^{\text {nd }}$ rank - "Mature love" $(M=4.56 ; S D=4.56 ; M d n(I Q R)=3(2-8.25))$;

- $3^{\text {rd }}$ rank - "Health" $(M=5.27 ; S D=4.6 ; M d n(I Q R)=4(2-7.25))$.

The results showed us that "Mature love" and "Health" were still important in both adolescence and in adulthood. However, the value of "True friendship" lost its position and in $2015^{\text {th }}$ the importance of "Family" took the $1^{\text {st }}$ rank. The least important values in both years 1998 and 2015 were:

- $18^{\text {th }}$ rank - "Pleasure";

- $17^{\text {th }}$ rank - "Salvation";

- $16^{\text {th }}$ rank - "A world of beauty".

Analyzing significant changes between 1998 and 2015 we found out that in terminal values, in 2015, increased importance of values: "Family" $(z=-2.06, p=0.04)$ and "Interesting job" $(z=-2.3, p=0.02)$; and importance decreased only in "True friendship" $(z=-2.64, p=0.008)$, but other value ranks did not change significantly. The importance of "Family" increased from $4^{\text {th }}$ rank to $1^{\text {st }}$; importance of "Interesting job" increased from $11^{\text {th }}$ rank to $5^{\text {th }}$ rank; importance of "True friendship" decreased from $2^{\text {nd }}$ rank to $6^{\text {th }}$ rank.

Secondly, the same structure was used to find out what instrumental values were the most important in 1998 and 2015 (Fig. 2). Rokeach most important instrumental values in 1998 were:

- $1^{\text {st }}$ rank - "Responsibility" $(M=6.56 ; S D=4.83 ; M d n(I Q R)=5(2-11))$;

- $2^{\text {nd }}$ rank - "Honesty" $(M=5.96 ; S D=4.41 ; M d n(I Q R)=5.5(2-9.25))$;

- $3^{\text {rd }}$ rank - "Cheerfulness" $(M=7.23 ; S D=4.94 ; M d n(I Q R)=6.5(2.75-10.25))$;

Rokeach most important instrumental values in 2015 were:

- $1^{\text {st }}$ rank - "Responsibility" $(M=5.13 ; S D=3.73 ; M d n(I Q R)=4(3-7.25))$;

- $2^{\text {nd }}$ rank - "Honesty" $(M=6 ; S D=4.98 ; M d n(I Q R)=5(1.75-10.25))$;

- $3^{\text {rd }}$ rank - "Cheerfulness" $(M=6.83 ; S D=5.27 ; M d n(I Q R)=6.5(2-10.5))$. 


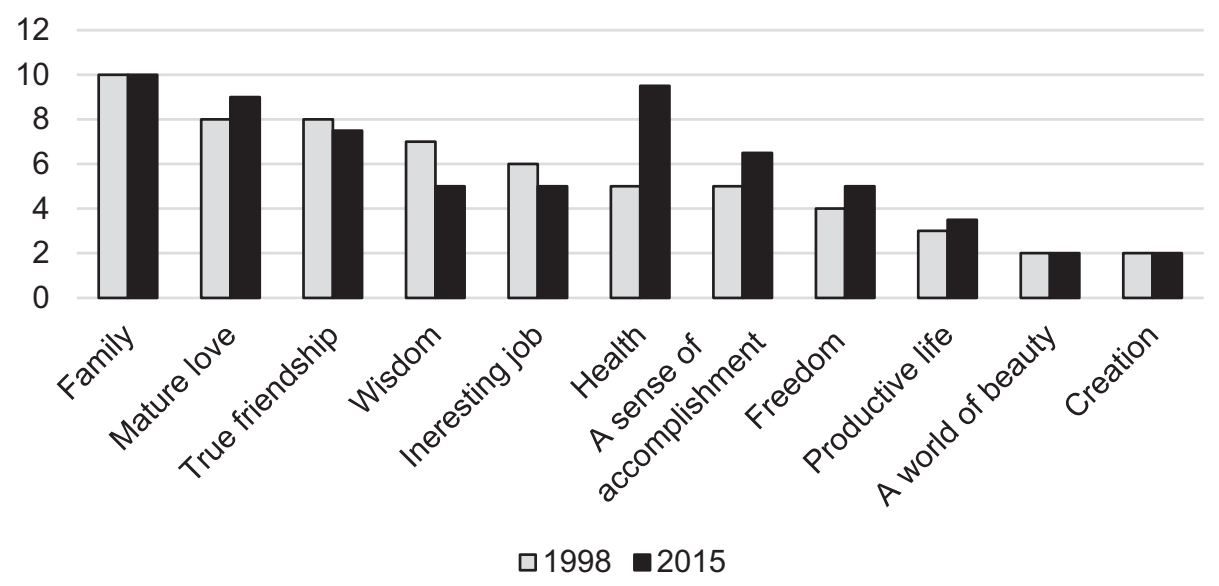

Fig. 3. Dynamics of important value hierarchy in 1998 and 2015 based on central tendency score where 11 - most important, 0 - less important.

Rokeach least important instrumental values in 1998 were:

- $18^{\text {th }}$ rank - Forgiveness $(M=15.96 ; S D=3.64 ; M d n(I Q R)=18(15-18))$;

- $17^{\text {th }}$ rank - Efficiency $(M=12.32 ; S D=5.03 ; M d n(I Q R)=14.5(6-16))$;

- $16^{\text {th }}$ rank - Ambition $(M=13.92 ; S D=3.75 ; M d n(I Q R)=14(10.75-17))$.

Rokeach least important instrumental values in 2015 were:

- $18^{\text {th }}$ rank - Forgiveness $(M=15.37 ; S D=4.68 ; M d n(I Q R)=18(13.75-18))$;

- $17^{\text {th }}$ rank - Ambition $(M=13.6 ; S D=4.83 ; M d n(I Q R)=16(11-17))$;

- $16^{\text {th }}$ rank - Capability $(M=12.57 ; S D=4.62 ; \operatorname{Mdn}(I Q R)=13(10-17))$.

Significant changes between 1998 and 2015 instrumental values appeared only in "Intellect" $(z=-2.16, p=0.03)$ which significantly decreased in 2015, importance of other instrumental value did not change significantly. The importance of "Intellect" decreased from $5^{\text {th }}$ rank to $11^{\text {th }}$.

\subsection{Fantalova "important" and "achievable" values}

To answer the question what values were the most "important" and the least "important" (Fig. 3), the most "achievable" and least "achievable" (Fig. 4) (by Fantalova) in 1998 and 2015 the descriptive statistics was used. To analyze the difference level between two years the Wilcoxon criteria were used.

Fantalova most important values in 1998 were:

- $1^{\text {st }}$ rank - "Family" $(M=8.44 ; S D=3.07 ; M d n(I Q R)=10(6.5-11))$;

- $2^{\text {nd }}$ rank - "Mature love" $(M=8.04 ; S D=2.35 ; M d n(I Q R)=8(6.5-10))$;

- $3^{\text {rd }}$ rank - "True friendship" $(M=7.88 ; S D=1.90 ; M d n(I Q R)=8(7-9))$;

Fantalova most important values in 2015 were:

- $1^{\text {st }}$ rank - "Family" $(M=8.93 ; S D=2.34 ; M d n(I Q R)=10(7.5-11))$;

- $2^{\text {nd }}$ rank - "Health" $(M=8.21 ; S D=2.87 ; M d n(I Q R)=10(6-11))$;

- $3^{\text {rd }}$ rank - "Mature love" $(M=8.62 ; S D=2.03 ; M d n(I Q R)=9(8-10))$. 


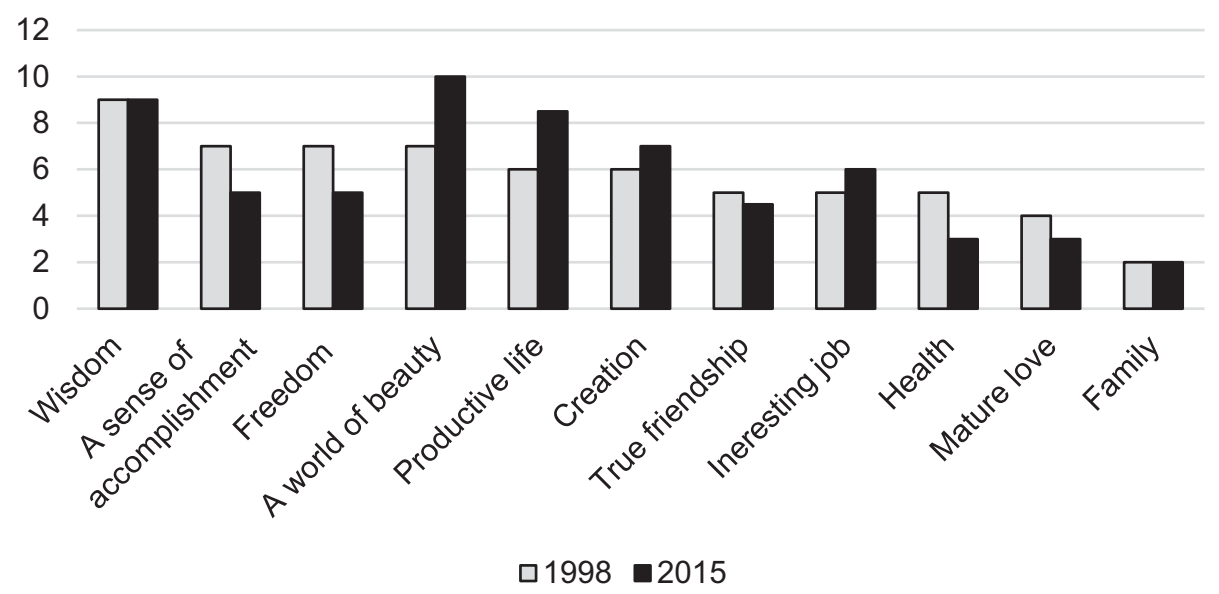

Fig. 4. Dynamics of achievable value hierarchy in 1998 and 2015 based on central tendency score where 11 - most achievable, 0 - less achievable.

Fantalova least important values in 1998 and 2015 were:

- $12^{\text {th }}$ rank - "Creation" $(M=2.72 ; S D=3.17 ; M d n(I Q R)=2(0-4.5)),(M=2.8$; $S D=2.28 ; \operatorname{Mdn}(I Q R)=2(1-4.52))$;

- $11^{\text {th }}$ rank - "A world of beauty" $(M=2.84 ; S D=2.25 ; \operatorname{Mdn}(I Q R)=2(1-4))$, $(M=2.13 ; S D=2.26 ; \operatorname{Mdn}(I Q R)=2(0-4))$;

$-10^{\text {th }}-$ "Productive life" $(M=3.32 ; S D=1.75 ; M d n(I Q R)=3(2-5)),(M=3.2$; $S D=2.23 ; \operatorname{Mdn}(I Q R)=3.5(1-5))$;

Results showed us that the values of "Health" replaced the "True friendship" in 2015. Other values did not change or changed insignificantly.

Important values that significantly changed comparing 1998 and 2015: increased in adults: "Health" $(z=-3.21, p=0.001)$, "A sense of accomplishment" $(z=-3.25, p=$ $0.001)$ and importance decreased in "Wisdom" $(z=-2.02, p=0.04)$, other values were permanent. The importance of "Health" increased from $6^{\text {th }}$ rank to $2^{\text {nd }}$; "A sense of accomplishment" from $7^{\text {th }}$ rank to $4^{\text {th }}$ rank and "Wisdom" decreased from $4^{\text {th }}$ rank to $7^{\text {th }}$ rank.

Fantalova most achievable values in year 1998 were:

- $1^{\text {st }}$ rank "Wisdom" $(M=6.36 ; S D=2.78 ; M d n(I Q R)=9(6-10))$;

- $2^{\text {nd }}$ rank "A world of beauty" $(M=7.04 ; S D=2.94 ; M d n(I Q R)=7(4-10))$;

- $3^{\text {rd }}$ rank "A sense of accomplishment" $(M=6.6 ; S D=3.52 ; \operatorname{Mdn}(\operatorname{IQR})=7(4-10))$;

Fantalova most achievable values in 2015:

- $1^{\text {st }}$ rank "A world of beauty" $(M=8.5 ; S D=2.95 ; M d n(I Q R)=10(7-10.25))$;

- $2^{\text {nd }}$ rank "Wisdom" $(M=8.23 ; S D=2.1 ; M d n(I Q R)=9(7-10))$;

- $3^{\text {rd }}$ rank "Productive life" $(M=8.17 ; S D=2.21 ; M d n(I Q R)=8.5(7-10))$.

Fantalova least achievable values in 1998 and 2015:

- $12^{\text {th }}$ rank "Family" $(M=3.28 ; S D=3.52 ; M d n(I Q R)=2(0.5-4.5)),(M=3.4$; $S D=3.33 ; \operatorname{Mdn}(I Q R)=2(1-5.25))$; 
- $11^{\text {th }}-$ "Mature love" $(M=4.72 ; S D=2.95 ; M d n(I Q R)=4(2-7)),(M=3.4$; $S D=2.28 ; \operatorname{Mdn}(I Q R)=3(2-5))$;

- $10^{\text {th }}-$ "Health" $(M=4.56 ; S D=2.4 ; M d n(I Q R)=5(3-6)),(M=3.47 ; S D=2.61$; $\operatorname{Mdn}(I Q R)=3(1-5.25))$.

Comparing 1998 and 2015 achievable values significantly increased in adults: "Productive life" $(z=-2.63, p=0.009)$, "Interesting job" $(z=-2.35, p=0.02)$, "A world of beauty" $(z=-1.99, p=0.05)$, and significantly decreased "A sense of accomplishment" $(z=$ $-2.51, p=0.01)$ and "Freedom" $(z=-2.14, p=0.03)$. "Productive life" increased from $5^{\text {th }}$ rank to $3^{\text {rd }}$ rank, "Interesting job" from $8^{\text {th }}$ rank to $5^{\text {th }}$ rank, "A world of beauty" from $4^{\text {th }}$ to $1^{\text {st }}$ rank, and decreased "A sense of accomplishment" from $2^{\text {nd }}$ rank to $6^{\text {th }}$ rank in adulthood.

\subsection{Fantalova index of difference between "important" and "achievable" values}

Other important results appeared in Fantalova index of difference between important and achievable values. Results showed that index significantly changed comparing 1998 and $2015(z=-3.45 ; p=0.002)$. The difference between important and achievable values in $2015(M=51.37 ; S D=14.1 ; M d n(I Q R)=57(46.75-62))$ was significantly higher than in $1998(M=35.77 ; S D=22.35 ; M d n(I Q R)=41(17.25-54.5))$. That means that in 1998 the difference between "important" and "achievable" was significantly higher than in 2015, and it leads us to the result that "important" and "achievable" values became more common in 2015 than in 1998.

\section{Discussion}

Few main conclusions were made according to the results of the study. It is important to note that in secondary data collection very specific sample participated - only $25 \%$ of initial sample, other $75 \%$ could not be found by personal information or have not responded to the request about the participation in research. We discovered that in the second wave of research participated people with only average incomes - neither very poor nor rich people participated possibly because they were unable to respond to the request about the research.

Results showed us few important findings. The findings of this research showed us that some values change during life but some stay the same. Other studies of adolescents' values in Latvia $[1-3,5,9]$ showed us that they all are mostly the same.

Firstly, both tests showed us the importance of family and mature love in both adolescence and in adulthood that let us discuss that these values may have been established in childhood. As we can see from sample description, majority of the participants was married or was in civil marriage, as well as majority has one or more children. That let us think that in their adulthood participants follow their values of love and family. Results generally were concurrent with M. Rokeach (1973) theory where he discussed that values are mostly persistent in time and determine peoples' choices [10].

Secondly, importance of health, interesting job and a sense of accomplishment significantly increased in adulthood comparing to adolescence. That let us think how people feel about their physical and mental comfort by the age of 30-33. The increase in these values shows us that participants started to care about their physical and mental health. The same results appeared in other studies [14-16] where important role was played by physical ageing as a motivational factor. 
Thirdly, importance of true friendship, intellect and wisdom decreased in adulthood. As well, majority of our participants finished higher education and were employed, which let us think about external social relationships that may have lost their value. These results may relate to overall self-content, which tends to appear in adulthood and makes desire for social acceptance and social contacts less important [17, 18].

Fourthly, the achievability of values like productive life, a world of beauty and interesting job increased in adulthood that let us consider that in elder life the productivity was evaluated by time. That may relate to biological ageing and a desire for mental well-being [14-16].

Fifthly, the achievability of freedom and a sense of accomplishment decreased in adulthood that may relate to Latvian socio-economic changes like crisis when a lot of work places disappeared, the salaries decreased. That may have influenced people who wanted an interesting job but could not get it because of lack of vacancies or small payments.

Sixthly, the index of difference between important and achievable values shows us that this index significantly changed comparing 1998 and 2015. The difference between important and achievable values in 2015 was significantly lower than in 1998, that let us consider that a person by the age of 30-33 becomes more realistic possibly because of getting cognitive maturity and getting it with his permanent values established in childhood. These results let us think that in adulthood people are more tended to self-control [19], which may relate to balancing of important and achievable values in their lives.

\section{Conclusions}

This paper provides insight of value differences between the same people important, achievable, terminal and instrumental values, comparing values in adolescence and in adulthood. We concluded that mostly values were permanent and only few changed significantly. It is important to highlight that values of mature love and family were the most important and permanent but the value of friends decreased and value of health increased in adulthood.

Generally, the present study allows us to conclude that in our specific sample, comparing people's values when they were 16-18 years old and then by the age of 30-33 years old - in adulthood person is reevaluating the most important values, tending to take care of physical and psychological health and is tending to closer social connections like family. This leads us to the limitations of this study - mostly in this research the average people have participated, not the extreme cases with some extraordinary life experience. For the future research, we are planning to study individuals whose results are different from others and try to reach extreme cases from the original study that could not participate in 2015 .

\section{References}

[1] S. Jirgena, Promocijas darbs, Jauniešu pašizjūta un adiktīvas uzvedības izvēle, Rīga: LU (1999)

[2] J. Ļevina, K. Mārtinsone, S. Mihailova, I. Gintere, Proc. Int. Sci. Conf. 3, 577-587 (2015)

[3] S. Jirgena, K. Mārtinsone, Sabiedrība un kultūra. Rakstu krājums IX: 112-119, Vērtību hierarhija: jauniešu salīdzinošais vērtējums 1998, un 2005, gadā (2007)

[4] S. Austruma, Rēzeknes augstskolas Izglītības un dizaina fakultāte, Jauniešu vērtības patēēetājsabiedrībā Latvijā: promocijas darbs (2012)

[5] I. Tunne, Jauniešu vērtības (Ríga: RaKa, 1999)

[6] T. Likitapiwat, W. Sereetrakul, S. Wichadee, Int. J. Psycholo. Res. 8(1), 109-18 (2015) 
[7] A. Maercker, X.C. Zhang, Z. Gao, Y. Kochetkov, S. Lu, Z. Sang, J. Margraf, Int. J. Clin. Health Psychol. 15(1), 8-17 (2015)

[8] S. Schwartz. J. Cross-Cultural Psychol. 42(2), 307-319 (2011)

[9] A. Pētersons, The Values of Latvian People XVII (Turiba University Conference, 2016)

[10] M. Rokeach, The nature of human values (Free Press, New York, 1973), 136

[11] Е.Б. Фанталова, Журнал Практикующего Психолога, 175-202, Психометрическое исследование показателей методики "Уровень соотношения ценности и доступности" (2011)

[12] M. Rokeach, J. Soc. Issues 24(1), 13-33 (1968)

[13] E. Karsa, Bakalaura darbs. Rīga: Rīgas Stradiņa Universitāte. Pieaugušo vērtību hierarhija un sociālo aktivitāšu dinamika 1998. un 2015. gadā: longitudināls pētījums (2015)

[14] Н.Ф. Шахматов. Психология зрелости и старения, 2, 16. Старениевремя личного познания вечных вопросов и истинных ченностей (1998)

[15] М.Г. Руднев, ИС РАН.-2009.-29 с. Базовые ченности населения: сравнение россиян с жителями других европейких стран (2009)

[16] Ю.В. Кузьмина, Самооченка уровня здоровья и образа жизни студентов во взаимосвязи с биосочиальными факторами и личностными ресурсами (2011)

[17] M. Sokola, Bakalaura darbs, Rīga: Rīgas Stradiņa Universitāte. Vērtības, dzīves jēgas orientācijas, pašattieksme 1998. un 2015.gadā: longitudināls pētījums (2016)

[18] Ю.С. Черкасова, О.В. Бубновская, Динамика Изменений Карьерных Ориентаций Участников Волонтерского Движения (На Примере Центра Волонтеров Вгуәс, Г. Владивосток (2015)

[19] Е.Г. Ожогова, Автореф. дисс. канд. психол. наук/ЕГ Ожогова. Саратов. Взаимосвязь синдрома "психического выгорания" и особенностеуи ченностно-смысловой сферь у педагогов общеобразовательных школ (2008) 